\title{
Amelioration of Saline Soil by the Application of Gypsum, Calcium Chloride, Rice Husk and Cow Dung
}

\author{
Mohammad Zulfikar Khan ${ }^{1}$, Mohammad Golam Azom¹, Mohammad Tipu Sultan'1, Sudipta Mandal' \\ Mohammad Ariful Islam', Rikta Khatun' ${ }^{1}$, Shaikh Motasim Billah¹, Abu Hena Mohammad Zulfikar Ali²
}

${ }^{1}$ Soil, Water and Environment Discipline, Khulna University, Khulna, Bangladesh

${ }^{2}$ Department of Soil, Water and Environment, University of Dhaka, Dhaka, Bangladesh

Email: *zulfikar.ku11@gmail.com

How to cite this paper: Khan, M.Z., Azom, M.G., Sultan, M.T., Mandal, S., Islam, M.A., Khatun, R., Billah, S.M. and Ali, A.H.M.Z. (2019) Amelioration of Saline Soil by the Application of Gypsum, Calcium Chloride, Rice Husk and Cow Dung. Journal of Agricultural Chemistry and Environment, 8, 78-91.

https://doi.org/10.4236/jacen.2019.82007

Received: March 3, 2019

Accepted: May 20, 2019

Published: May 23, 2019

Copyright $\odot 2019$ by author(s) and Scientific Research Publishing Inc. This work is licensed under the Creative Commons Attribution International License (CC BY 4.0).

http://creativecommons.org/licenses/by/4.0/

\begin{abstract}
A pot experiment was conducted to investigate the effect of cow dung, rice husks, calcium chloride and gypsum on soil reclamation and compare the effect of organic and inorganic amendments on soil reclamation during the period of $5^{\text {th }}$ March to $20^{\text {th }}$ April, 2017. The experiment was laid to fit a completely randomized design (CRD) with seven treatments [Reference soil $\left(\mathrm{T}_{0}\right)$, Cow dung $\left(\mathrm{T}_{1}\right)$, Rice husk $\left(\mathrm{T}_{2}\right)$, Gypsum $\left(\mathrm{T}_{3}\right)$, Calcium chloride $\left(\mathrm{T}_{4}\right)$, Cow dung + Rice husk $\left(\mathrm{T}_{5}\right)$ and Gypsum + Calcium chloride $\left(\mathrm{T}_{6}\right)$ ] each having three replications for this experiment. After incubation (45 days), the laboratory investigation was carried out in the Soil, Water and Environment Discipline, Khulna University, Khulna, Bangladesh. Results indicate that the individual or combined effect of gypsum $\left(\mathrm{T}_{3}\right)$ was more effective in changing EC and SAR. Gypsum application in combination with calcium chloride $\left(\mathrm{T}_{6}\right)$ improved the soil chemical properties by reducing the EC. Among the treatment, calcium chloride $\left(\mathrm{T}_{4}\right)$ had a remarkable effect in reducing sodium adsorption ratio and gypsum had a remarkable effect in reducing $\mathrm{pH}$. Cow dung $\left(T_{1}\right)$, rice husk $\left(T_{2}\right)$, combination of cow dung and rice husk $\left(T_{5}\right)$ were less effective to reduce EC, $\mathrm{pH}$ and SAR. It's measured for soils of different soil amendments varied significantly $(P<0.05)$ and also with the reference soil.
\end{abstract}

\section{Keywords}

Amelioration, Saline Soil, Cow dung, Rice Husk, Gypsum, Calcium Chloride, C/N Ratio

\section{Introduction}

Salinization of land is one of the most important problems in South and 
South-West coastal parts of Bangladesh. The total area of Bangladesh is 147,570 $\mathrm{km}^{2}$. The coastal area covers about $20 \%$ of the country. Over $30 \%$ of the net cultivable area in Bangladesh is on the coast [1]. Out of the 2.85 million hectares (mha) of coastal and off-shore area (30\% of net cultivable area), about $0.83 \mathrm{mha}$ arable land were affected by varying degrees of soil salinity during 1966-1975 which has increased to $1.02 \mathrm{mha}$ in 2000 [2]. The coastal soil salinity has undergone rapid changes in recent years. Such changes occur due to conversion and encroachment of agricultural land to shrimp farming. Transformation of rice fields into shrimp farms has changed the land use because the rain-water cannot wash out the salt water now rather it stored in "Gher". So, salinity increases day by day and form salt crust in sub-surface.

Bangladesh, a low-lying deltaic land, is particularly vulnerable to climate change and its associated hazards [3]. The coastal areas of Bangladesh, with its near flat topography and location at the tip of "funnel shaped" Bay of Bengal, are susceptible to a number of natural hazards: cyclones and tidal surges, salinity intrusion, riverbank erosion, shoreline recession etc. [4]. Although all hazards are detrimental to agriculture, however sea level rise is likely to put the gravest threat by land submersion and salinity intrusion [5] [6]. Irrigated water demand is highly affected by salinity intrusion in surface water [7] and salt accumulation in the root zone of soil affects plant growth in coastal soil [8]. Besides constraining agricultural production, salinity limits the fresh water availability for drinking purpose and industrial production. Coastal area of Bangladesh has already been experiencing erosion. It has been found that the sea level rise of $0.5 \mathrm{~m}$ over the last 100 years has eroded approximately $162 \mathrm{~km}^{2}$ of Kutubdia, $147 \mathrm{~km}^{2}$ of Bhola and $117 \mathrm{~km}^{2}$ of Sandwip [9]. Based on 22 years data, SAARC Meteorological Research Council (SMRC) found that the sea level rise in Hiron point, Char Ganga and Cox's Bazar, three tidal stations of Bangladesh, was $4.0 \mathrm{~mm} /$ year, 6.0 $\mathrm{mm} /$ year and $7.8 \mathrm{~mm} /$ year, respectively [10]. If the trend continues, sea water may intrude much longer distance in inland extending towards interior coast in low-laying areas of Bangladesh [11]. Being an agrarian country, $60 \%$ people of Bangladesh are directly or indirectly dependent on agriculture for their livelihood, with the contribution of $20 \%$ to its GDP [12]. The dominant land use in coastal Bangladesh is also agriculture. Even though gross and net-cropped areas in the coastal zone of Bangladesh are 144,085 and 83,416 hectors, respectively [13], but net-cropped area of coastal zone has been showing a decreasing trend over the years due to a combination of factors. Gowing et al. [14] argued that coastal Agri-lands often suffered from saline intrusion that prevented crop production in dry season. CCC study identified salinity intrusion as the most pressing problem for yield reduction in coastal agriculture. The study found that 830,000 million hectares of land at coastal Bangladesh were affected by soil salinity at different degrees. It is estimated that a net reduction of 0.5 million MT of rice production would take place due to a $0.3 \mathrm{~m}$ sea level rise in coastal areas of Bangladesh [15].

There are many different methods of reclamation of saline soils such as phys- 
ical amelioration (deep ploughing, sub-soiling, sanding, profile inversion), chemical amelioration (amending of soil with various reagents e.g., gypsum, calcium chloride, limestone, sulphuric acid, sulphur, iron sulphate), electro-reclamation (treatment with electric current) [16]. Though the amelioration of saline soils with chemical amendments is an established technology [17] [18], the chemical strategies, however, have become costly for subsistence farmers in the developing countries during the last two decades because of the increased use by industry and reductions in government subsidy to farmers for their purchase [19]. Organic manures not only increase soil fertility, but enhance soil chemical and physical properties [20]. The biological amelioration methods using living or dead organic matter such as crops, stems, straw, green manure, barnyard manure, compost, sewage sludge have two principal beneficial effects on reclamation of saline and alkaline soils: improvement of soil structure and permeability thus enhancing salt leaching, reducing surface evaporation and inhibition of salt accumulation in surface soils, and release of carbon dioxide during respiration and decomposition [21]. Therefore, the main objectives of this research were to investigate the effect of cow dung, rice husks, calcium chloride and gypsum on soil reclamation and compare the effect of organic and inorganic amendments on soil reclamation.

\section{Methods and Materials}

A pot experiment was conducted in the net house at the premises of the Soil, Water and Environment Discipline, Khulna University, Khulna, Bangladesh during the Kharif season from $5^{\text {th }}$ March to $20^{\text {th }}$ April, 2018 to investigate the effect of cow dung, rice husks, calcium chloride and gypsum on soil reclamation and compare the effect of organic and inorganic amendments on soil reclamation. The net house experiment, collection and preparation of soil samples and analytical methods adopted during the course of investigation were presented in this chapter.

Soil sample collection and preparation

Soil samples were collected at a depth of $0-15 \mathrm{~cm}$ from a square area of $1 \mathrm{~km}^{2}$ under Bagerhat district (GPS: $22^{\circ} 40.542^{\prime} \mathrm{N}$ and $89^{\circ} 31.406^{\prime} \mathrm{E}$ ) in Bangladesh. Then sample were mixed together to form a composite sample. After air drying, the larger aggregates were broken gently by crushing it in a wooden hammer, and passed through a $2 \mathrm{~mm}$ sieve. The sieved soils were preserved in plastic bag for pot experiment and also preserved in plastic pot for determining their various physical and chemical properties and both are labeled properly. General information of the experimental soil was shown in Table 1.

Experimental design and treatments

A pot experiment was carried out in net house of Soil, Water and Environment Discipline at Khulna University. The study was arranged in a completely randomized design (CRD) [22] using seven treatments replicated three times (Table 2). Each pot containing $3 \mathrm{~kg}$ of air-dried soil with different combinations 
Table 1. General information about sampling sites.

\begin{tabular}{cc}
\hline & General information \\
\hline Location & Village: Harikhali; Upazilla: Bagerhat; District: Bagerhat \\
GPS & $22^{\circ} 40.542^{\prime} \mathrm{N}$ and $89^{\circ} 31.406^{\prime} \mathrm{E}$ \\
EC & $8.30 \mathrm{dS} \cdot \mathrm{m}^{-1}$ \\
pH & 8.45 \\
SAR & 2.01 \\
CEC & 20.4 Cmolc $(+) \mathrm{kg}^{-1}$ \\
$\% O C$ & $0.78 \%$ \\
$\% O M$ & $1.35 \%$ \\
$\% \mathrm{~N}$ & $0.14 \%$ \\
C:N & 5.6 \\
Calcareousness & Calcareous \\
Textural class & Silty clay \\
\hline
\end{tabular}

Table 2. Treatment of the experiment.

\begin{tabular}{cc}
\hline Treatment & Description \\
\hline $\mathrm{T}_{0}$ & Reference soil (Indigenous soil) \\
$\mathrm{T}_{1}$ & Cow dung \\
$\mathrm{T}_{2}$ & Rice husk \\
$\mathrm{T}_{3}$ & Gypsum \\
$\mathrm{T}_{4}$ & Calcium chloride \\
$\mathrm{T}_{5}$ & Cow dung + Rice husk \\
$\mathrm{T}_{6}$ & Gypsum + Calcium chloride \\
\hline
\end{tabular}

of the amendments were prepared as follows.

The application rate of amendments for $\mathrm{T}_{1}, \mathrm{~T}_{2}, \mathrm{~T}_{3}$ and $\mathrm{T}_{4}$ was $3000 \mathrm{~kg}$ per hectare. For $\mathrm{T}_{5}$ half of cow dung + half of rice husk (3000 kg cow dung per ha + $3000 \mathrm{~kg}$ rice husk per ha) and for $\mathrm{T}_{6}$ half of gypsum + half of calcium chloride (3000 kg gypsum per ha $+3000 \mathrm{~kg}$ calcium chloride per ha) were applied. These pots were incubated in net house of Soil, Water and Environment Discipline at Khulna University for 45 days under $25^{\circ} \mathrm{C}$ temperature. Field condition was maintained by the addition of water in weekly intervals during the period of incubation.

\section{Analytical procedure}

Different physical and chemical parameters of soil were analyzed by following procedures. Electrical conductivity (EC) of soil was estimated by EC meter maintaining the ratio of soil to water of $1: 5$ and then the result was converted to the ratio of 1:1 (soil:water) as suggested by USDA [23]. The pH value of soil samples was measured by using $\mathrm{pH}$ meter maintaining the ratio of soil to water of 1:2.5 as suggested by Jackson [24]. Organic Carbon of soil samples was deter- 
mined by Walkley Black's Wet Oxidation method as outlined by Jackson [25]. Organic matter was calculated by multiplying the percent value of organic carbon with the conventional Van-Bemmelene's factor of 1.724 [26]. The CEC of the soils was determined by extracting the soil with neutral ammonium acetate solution $\left(\mathrm{NH}_{4} \mathrm{OAc}, \mathrm{pH}-7\right)$ by the replacing the ammonium in the exchange complex by $1 \mathrm{~N} \mathrm{KCl}$ solution and the result recorded by flame photometric method [24]. The total Nitrogen of the soil was determined by Micro-Kjeldahl's method following $\mathrm{H}_{2} \mathrm{SO}_{4}$ acid digestion as suggested by Jackson [25]. Available $\mathrm{Ca}^{2+}$ and $\mathrm{Mg}^{2+}$ was extracted with $1 \mathrm{~N} \mathrm{NH}_{4} \mathrm{OAc}$ solution (pH 7.0) as described by Piper [26] and Jackson [27] and measured by atomic adsorption spectrophotometer. Sodium $\left(\mathrm{Na}^{+}\right)$content in soil samples was determined separately by Flame emission spectrophotometer (Model: Jenway, PEP-7) using Sodium filter, as outlined by Jackson [27]. Sodium adsorption ratio was calculated by the equation: $\mathrm{SAR}=\left[\mathrm{Na}^{+}\right] /\left[\mathrm{Ca}^{2+}+\mathrm{Mg}^{2+}\right]^{1 / 2}[28]$.

Statistical analysis

The ANOVA and Duncan Multiple Range Test (DMRT) were done for completely randomized design by using the SAS 6.12 software package [29].

\section{Results and Discussions}

This experiment was to investigate the effect of cow dung, rice husks, calcium chloride and gypsum on soil reclamation and compare the effect of organic and inorganic amendments on soil reclamation. The results pertaining to the investigations are presented in this chapter.

Effect of different soil amendments on electrical conductivity (EC) in soil

The electrical conductivity measured for soils of different soil amendments varied significantly $(P<0.05)$ and also with the reference soil and the Electrical Conductivity (EC) measured for the soils varied from 5.14 to $8.30 \mathrm{dS} \cdot \mathrm{m}^{-1}$ as presented in Appendix I and Figure 1. The highest EC $\left(7.67 \mathrm{dS} \cdot \mathrm{m}^{-1}\right)$ was measured at rice husk treated soil. The magnitude of the differences is at the order of $\mathrm{T}_{2}>$ $\mathrm{T}_{5}>\mathrm{T}_{1}>\mathrm{T}_{4}>\mathrm{T}_{3}>\mathrm{T}_{6}$. So, among the treatment's gypsum $+\mathrm{CaCl}_{2}$ treatment significantly $(P<0.05)$ decreased the EC $\left(5.14 \mathrm{dS} \cdot \mathrm{m}^{-1}\right)$ of the soil presented the

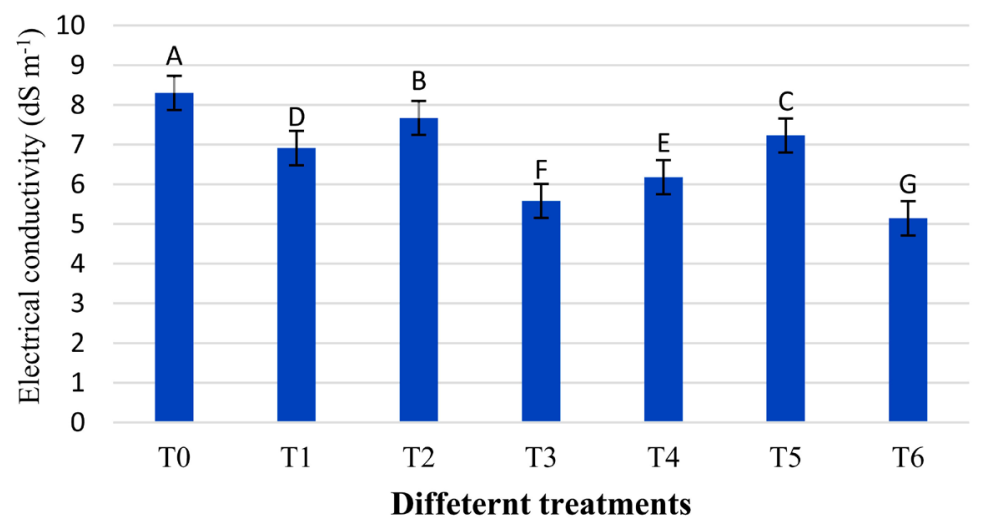

Figure 1. Effects of different soil amendments on Electrical Conductivity (EC) in soil. 
in Figure 1. $\mathrm{CaCl}_{2}$ proved less effective as compared to gypsum for soil amelioration. Sharma et al. [30] reported decrease in EC as a result of gypsum application. Organic amendments (cow dung and rice husk) also decreased EC and the numerical value of rice husk significantly $(P<0.05)$ lower than that of reference soil. The decreasing trend of EC might be due to leaching followed by the addition of organic amendments for releasing organic acids during decomposition, which was responsible for leaching of salts. Rehman et al. [31] achieved a substantially decreased EC of saline-sodic soils with the addition of different organic amendments. Decreased EC was the result of organic matter triggered leaching of excessive ions by improving the physical properties of soil.

Effect of different soil amendments on $\mathrm{pH}$ in soil

The $\mathrm{pH}$ measured for soils of different soil amendments varied significantly $(P$ $<0.05)$ with the reference soil and the $\mathrm{pH}$ measured for the soils varied from 8.20 to 8.32 as presented in Appendix I and Figure 2. The highest $\mathrm{pH}$ (8.32) was measured at cow dung treated soil. The magnitude of the differences is at the order of $\mathrm{T}_{1}>\mathrm{T}_{5}>\mathrm{T}_{6}>\mathrm{T}_{4}>\mathrm{T}_{2}>\mathrm{T}_{3}$. The $\mathrm{pH}$ was found 8.2 for gypsum, 8.226 for rice husk; 8.27 for both $\mathrm{CaCl}_{2}$ and $\mathrm{CaCl}_{2}+$ gypsum; 8.32 for rice husk + cow dung combination and 8.32 for cow dung are presented in the Figure 2. Differences between treatments to control were significant $(P<0.05)$. Lowest value recorded for gypsum treated soil. This might be due to water promoted gypsum dissolution, expediting the reclamation reactions and due to improvement of soil [32]. Organic amendments only showed a slight decrease in the $\mathrm{pH}$ of 8.326 for cow dung, and 8.226 for rice husk in comparison to the control. This may due to acidifying effect of organic acids produced during the course of decomposition of organic amendments. Guidi and Hall [33] observed that the application of various organic materials decreased the $\mathrm{pH}$ values due to organic and inorganic acids formed when organic matter decomposition takes place. There was no significant $(P<0.05)$ difference between cow dung treated soil and cow dung + rice husk treated soil and also between gypsum $+\mathrm{CaCl}_{2}$ treated soil and $\mathrm{CaCl}_{2}$ treated soil; also, between Rice husk treated soil and gypsum treated soil at 5\% level of significance.

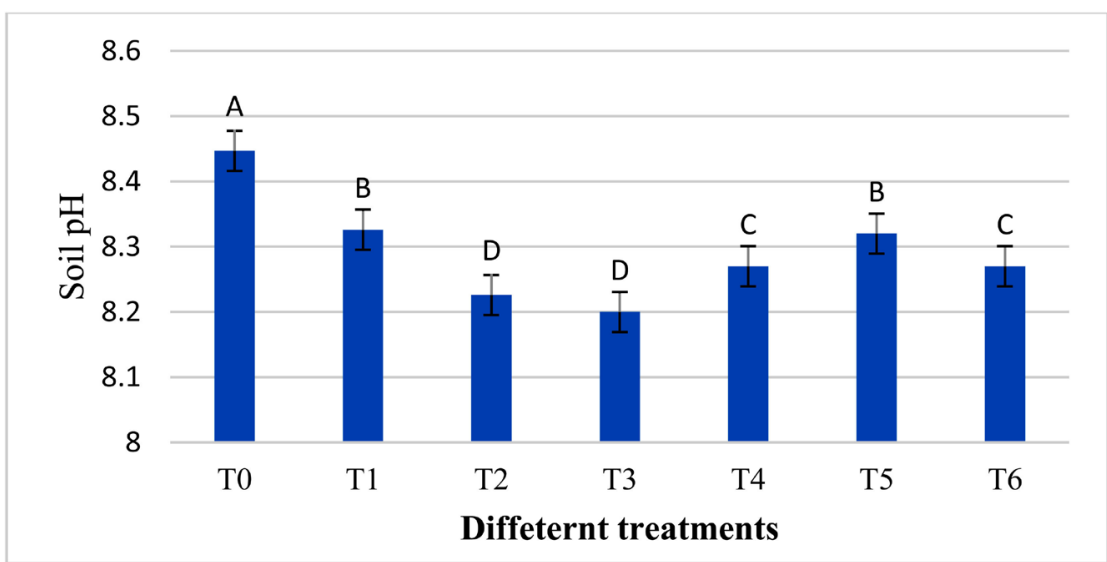

Figure 2. Effects of different soil amendments on $\mathrm{pH}$ in soil. 
Effect of different soil amendments on sodium adsorption ratio (SAR) in soil

The sodium adsorption ratio (SAR) measured for soils of different soil amendments varied significantly $(P<0.05)$ compared to reference soil and the sodium adsorption ratio measured for the soils varied from 1.01 to 1.45 as presented in Appendix I and Figure 3. The highest SAR (1.45) was measured at cow dung treated soil. The magnitude of the differences is at the order of $T_{1}>$ $\mathrm{T}_{5}>\mathrm{T}_{2}>\mathrm{T}_{6}>\mathrm{T}_{3}>\mathrm{T}_{4}$. A clear decrease of SAR was observed for amended soils presented in the Figure 3. The decrease in SAR due to either increase in divalent cations $\left(\mathrm{Ca}^{2+}\right.$ and $\left.\mathrm{Mg}^{2+}\right)$, or decrease in monovalent cation $\left(\mathrm{Na}^{+}\right)$. The measured values of cations indicated that $\mathrm{Na}^{+}$decreased while $\mathrm{Ca}^{2+}$ increased in the exchangeable complex after the application of organic and inorganic amendments followed by leaching. The relatively high mobility and leachability of $\mathrm{Na}^{+}$from soil due to the applied amendments as compared with $\mathrm{Ca}^{2+}$ resulted in lower values of SAR, hence, the SAR values of the treated soil were sharply decreased. Effect of ameliorant and its combinations were significantly different at $5 \%$ significant level compare to reference soil. Gypsum only or combination with inorganic amendments proved superior to organic amendments only for treatments in reducing SAR. A decrease in SAR with simple leaching in control was likely due to mineral weathering and leaching out from the soil [34]. Chorom and Rengasamy [35] reported that gypsum applied to the soil was more effective in reducing the SAR than an equivalent amount of $\mathrm{CaCl}_{2}$.

\section{Effect of amendments on cation exchange capacity (CEC) in soil}

The Cation Exchange Capacity (CEC) measured for soils of different soil amendments varied significantly $(P<0.05)$ compared to reference soil and the CEC measured for the soils varied from 19.73 to 27.72 Cmolc (+) $\mathrm{kg}^{-1}$ as presented in Appendix I and Figure 4. Among seven treatments except $\mathrm{CaCl}_{2}, \mathrm{CEC}$ was increased significantly compared to reference soil presented in the Figure 4 . The CEC was decreased in $\mathrm{CaCl}_{2}$ treated soil (19.73 Cmolc (+) $\mathrm{kg}^{-1}$ ) compared to reference soil $\left(20.40 \mathrm{Cmolc}(+) \mathrm{kg}^{-1}\right)$. But there was no significant difference between these treatments at $5 \%$ level of significance. The highest $(27.72 \mathrm{Cmolc}$ $(+) \mathrm{kg}^{-1}$ ) CEC was observed in gypsum $+\mathrm{CaCl}_{2}$ treated soil. The CEC of Cow dung + Rice husk treated soil was $21.73 \mathrm{Cmolc}(+) \mathrm{kg}^{-1}$. So, there was a

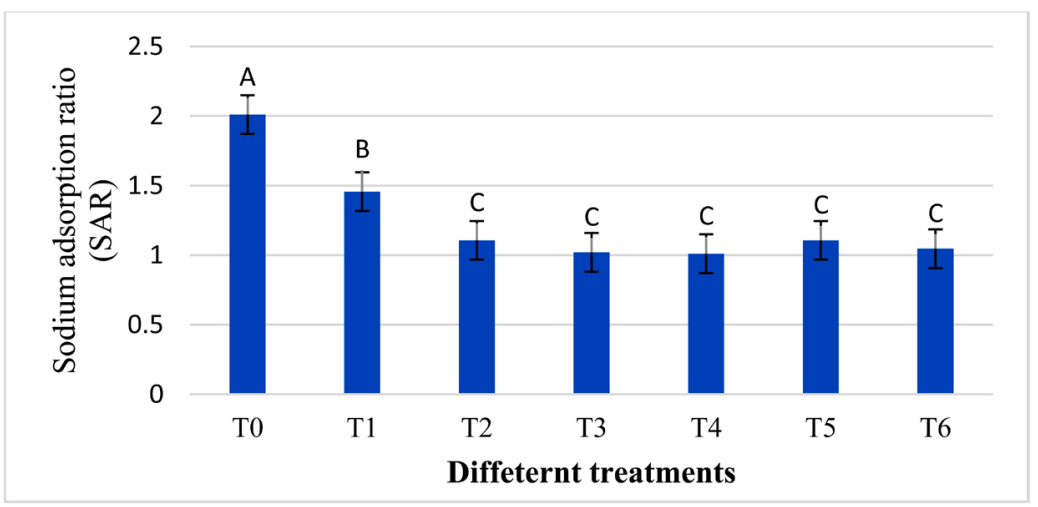

Figure 3. Effects of different soil amendments on sodium adsorption ratio (SAR) in soil. 
significant difference between combined applications of organic and inorganic treatment at 5\% level of significance. The CEC of rice husk treated soil was 25.05 Cmolc $(+) \mathrm{kg}^{-1}$. There was no significant difference among cow dung treated soil; cow dung + rice husk treated soil and gypsum treated soil at $5 \%$ level of significance.

\section{Effect of different soil amendments on organic carbon (\%) in soil}

The \%OC measured for soils of different soil amendments varied significantly $(P<0.05)$ compared to reference soil and the \%OC measured for the soils varied from 0.57 to 0.95 as presented in Appendix I and Figure 5. The effect of amendments on \%OC in saline soil were significantly different compared to control as presented in Figure 5. The \%OC was reduced to $0.57 \%$ compared to control $0.78 \%$. The highest $\% \mathrm{OC}$ was observed in cow dung + rice husk treated soil $(0.95 \%)$. The $\% \mathrm{OC}$ of cow dung treated soil and rice husk treated soil $0.89 \%$ and $0.87 \%$ respectively but there was no significant difference between these treatments at $5 \%$ level of significance. The $\% \mathrm{OC}$ of $\mathrm{CaCl}_{2}$ treated soil and gypsum treated soil were $0.74 \%$ and $0.70 \%$ respectively and there was significant difference at $5 \%$ level of significance. So, the $\% \mathrm{OC}$ was increased with the application of organic amendments and decreased with the application of inorganic amendments as compared to reference soil.

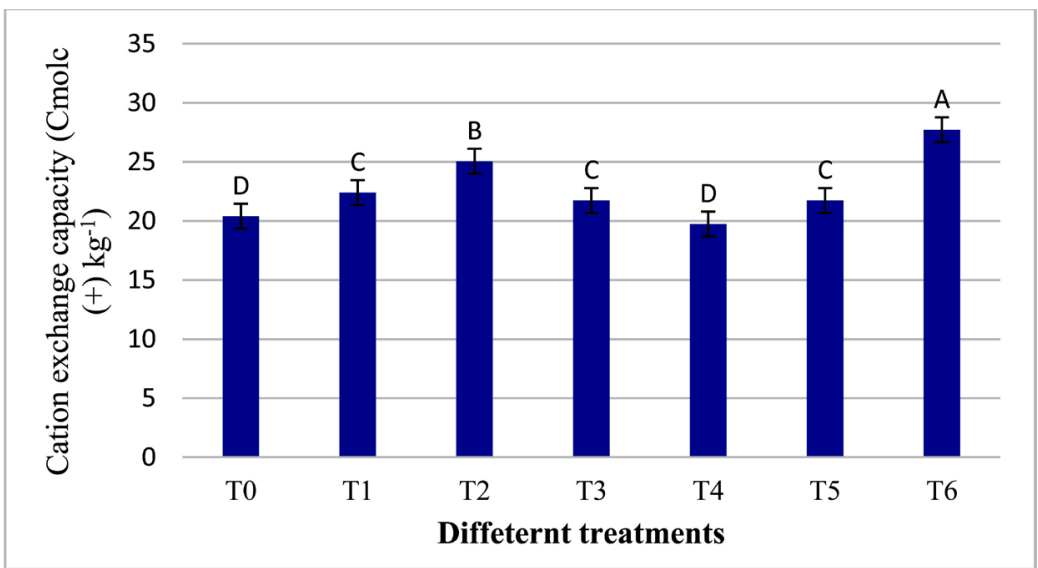

Figure 4. Effects of different soil amendments on cation exchange capacity (CEC) in soil.

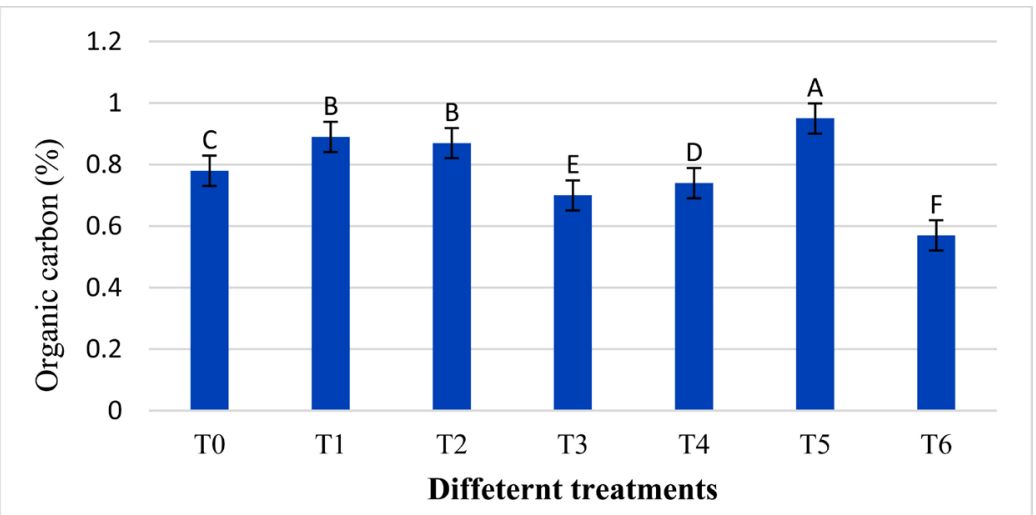

Figure 5. Effects of different soil amendments on organic carbon (\%) in soil. 


\section{Effect of different soil amendments on organic matter (\%) in soil}

The \%OM measured for soils of different soil amendments varied significantly $(P<0.05)$ compared to reference soil and the \%OM measured for the soils varied from $0.98 \%$ to $1.63 \%$ as presented in Appendix I and Figure 6. The effect of amendments on \%OM in saline soil was significantly different compared to reference soil as presented in Figure 6. The \%OM was reduced to $0.98 \%$ compared to reference soil $(1.34 \%)$. The highest $\% \mathrm{OM}$ was observed in cow dung + rice husk treated soil (1.63\%). The \%OM of cow dung treated soil and rice husk treated soil were $1.53 \%$ and $1.49 \%$ respectively but there was no significant difference between these treatments at $5 \%$ level of significance. The $\% \mathrm{OM}$ of $\mathrm{CaCl}_{2}$ treated soil and gypsum treated soil were $1.27 \%$ and $1.20 \%$ respectively and there was significant difference between these treatments at $5 \%$ level of significance. So, the \%OM was increased with the application of organic amendments and decreased with the application of inorganic amendments as compared to reference soil.

Effect of different soil amendments on nitrogen (\%) in soil

The $\% \mathrm{~N}$ measured for soils of different soil amendments varied significantly $(P<0.05)$ compared to reference soil and the $\% \mathrm{~N}$ measured for the soils varied from $0.04 \%$ to $0.21 \%$ as presented in Appendix I and Figure 7. The $\% \mathrm{~N}$ was reduced to $0.04 \%$ compared to control $0.14 \%$. The highest $\% \mathrm{~N}$ was observed in

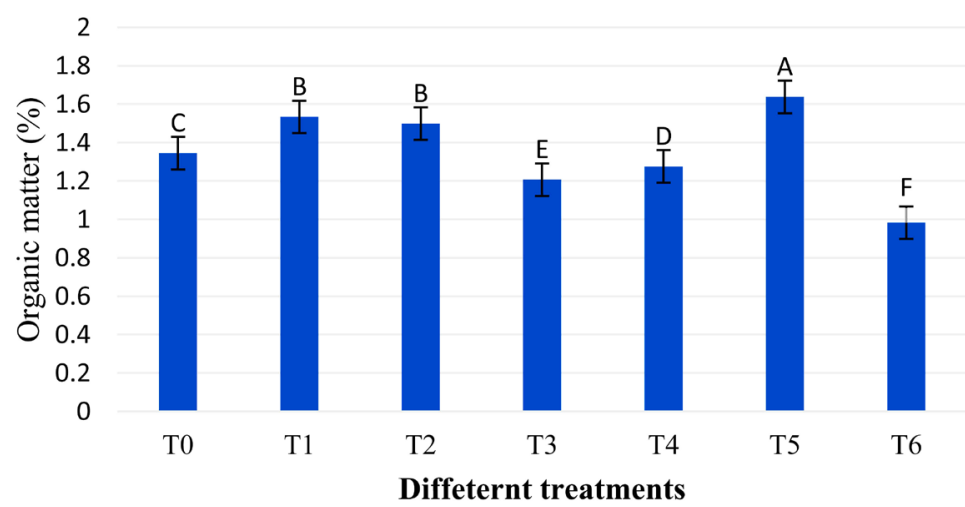

Figure 6. Effects of different soil amendments on organic matter (\%) in soil.

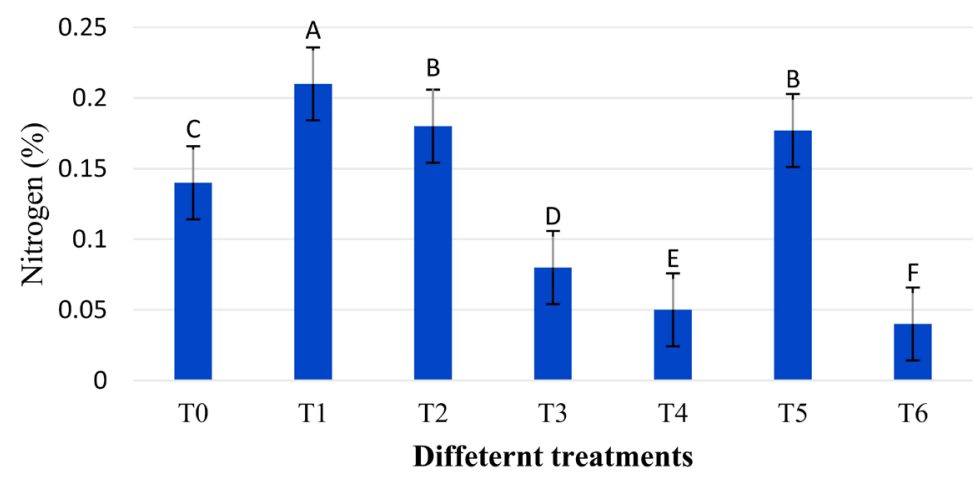

Figure 7. Effects of different soil amendments on nitrogen (\%) in soil. 
cow dung treated soil $(0.21 \%)$. The nitrogen (\%) of cow dung + rice husk treated soil and rice husk treated soil were $0.17 \%$ and $0.18 \%$ respectively but there was no significant difference between these treatments at $5 \%$ level of significance. The $\% \mathrm{~N}$ of $\mathrm{CaCl}_{2}$ treated soil and gypsum treated soil were $0.05 \%$ and $0.08 \%$ respectively and there was significant difference at $5 \%$ level of significance. So, the $\% \mathrm{~N}$ was increased with the application of organic amendments and decreased with the application of inorganic amendments as compared to reference soil.

Effect of different soil amendments on carbon/nitrogen ratio $(C / N)$ in soil

The effect of amendments on $\mathrm{C} / \mathrm{N}$ ratio in saline soil were significantly $(P<$ $0.05)$ different compared to reference soil and inorganic treatments presented in Appendix I and Figure 8. The $\mathrm{C} / \mathrm{N}$ ratio were reduced to 4.24 for Cow dung treated soil; reduced to 4.84 for Rice husk treated soil and reduced to 5.38 for cow dung + rice husk treated soil as compared to reference soil (5.59). The highest $\mathrm{C} / \mathrm{N}$ ratio was observed in gypsum treated soil (14.24) and the $\mathrm{C} / \mathrm{N}$ ratio of gypsum $+\mathrm{CaCl}_{2}$ treated soil was 13.26 but there was no significant difference between these treatments at $5 \%$ level of significance. The $\mathrm{C} / \mathrm{N}$ ratio of $\mathrm{CaCl}_{2}$ treated soil was 8.84 and there was significant difference among other two inorganic amendments at $5 \%$ level of significance. So, the $\mathrm{C} / \mathrm{N}$ ratio was increased with the application of inorganic amendments and decreased with the application of organic amendments as compared to reference soil.

\section{Conclusion}

The study revealed that the addition of cow dung, rice husk, gypsum and calcium chloride acted as ameliorants to saline soil. In this study, individual or combined effect of gypsum $\left(\mathrm{T}_{3}\right)$ was more effective in changing EC and SAR. Gypsum application in combination with calcium chloride $\left(\mathrm{T}_{6}\right)$ improved the soil chemical properties by reducing the EC. Among the treatment, calcium chloride $\left(\mathrm{T}_{4}\right)$ had a remarkable effect in reducing sodium adsorption ratio and gypsum had a remarkable effect in reducing $\mathrm{pH}$. Cow dung $\left(\mathrm{T}_{1}\right)$, rice husk $\left(\mathrm{T}_{2}\right)$, combination of

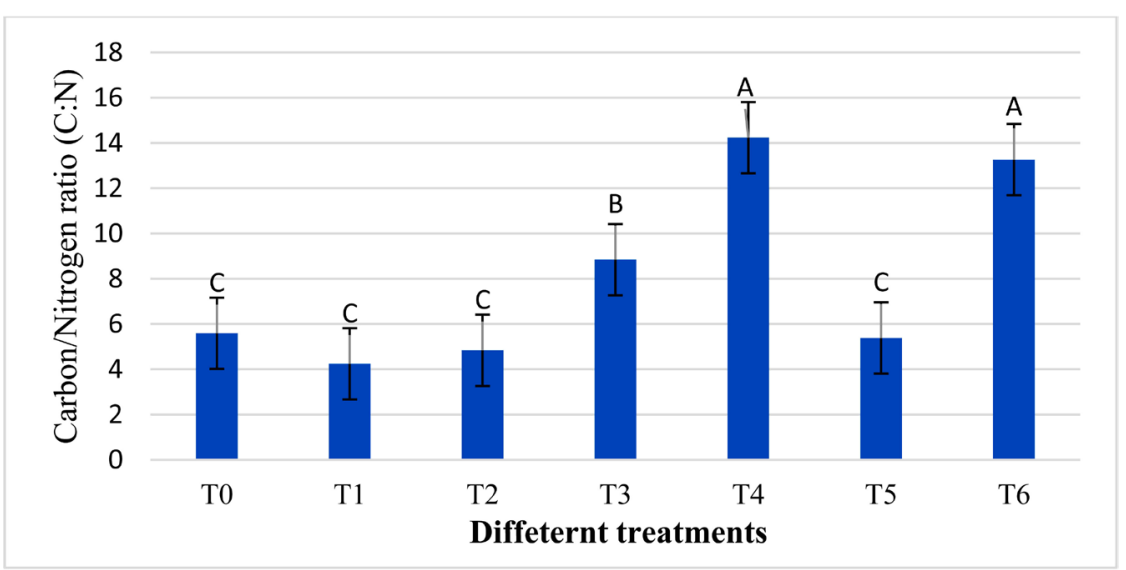

Figure 8. Effects of different soil amendments on Carbon/Nitrogen ratio $(\mathrm{C} / \mathrm{N})$ ratio in soil. 
cow dung and rice husk $\left(\mathrm{T}_{5}\right)$ were less effective to reduce EC, $\mathrm{pH}$ and SAR. So, inorganic amendments were superior to organic amendments to reduce salinity. On the other hand, the combined effect of cow dung and rice husk $\left(\mathrm{T}_{5}\right)$ was more effective to increase organic carbon and organic matter. Individual effect of cow dung $\left(\mathrm{T}_{1}\right)$ and rice husk $\left(\mathrm{T}_{2}\right)$ also had remarkable effect in increasing organic carbon and organic matter. Among the treatments, the combined application of gypsum and calcium chloride $\left(\mathrm{T}_{6}\right)$ had remarkable effect in reducing organic carbon as well as organic matter. Individual application of gypsum $\left(\mathrm{T}_{3}\right)$ and calcium chloride $\left(\mathrm{T}_{4}\right)$ also decreased organic carbon and organic matter. Individual effect of cow dung $\left(T_{1}\right)$ had remarkable effect in increasing nitrogen. Rice husk $\left(\mathrm{T}_{2}\right)$ also increased the nitrogen percentage slightly. So, organic amendments are superior to inorganic amendments to increase organic carbon, organic matter and nitrogen percentage. Though the inorganic amendments are better than organic to ameliorate soil, the use of organic amendments is sustainable to soil health.

\section{Acknowledgements}

All praise is to supreme being, creator and ruler of the universe whose mercy enables the authors to finish this research work. We thank Professor Dr. Shaikh Motasim Billah for their sincere supervision, valuable instruction for completion of this research work. We also thank an anonymous reviewer for their constructive criticism of the script and their valuable suggestions. This paper is dedicated to Md. Golam Azom who collected soil sample and different soil amendments with her cordial cooperation.

\section{Conflicts of Interest}

The authors declare no conflicts of interest regarding the publication of this paper.

\section{References}

[1] Brammer, H. (1971) Agricultural Development Possibilities in Bangladesh. Soil Survey Project Technological Report, United Nations Development Program, FAO, Rome.

[2] Khan, M.S., Rahman, M.M., Begum, R.A., Alam, M.K., Mondol, A.T.M.A.I., Islam, M.S. and Salahin, N. (2008) Research Experiences with Problem Soils of Bangladesh. Soil Science Division, Bangladesh Agricultural Research Institute (BARI), Joydebpur, 1-176.

[3] Agrawala, S., Ota, T., Ahmed, A.U., Smith, J. and Aalst, M.V. (2003) Development and Climate Change in Bangladesh: Focus on Coastal Flooding and the Sunderbans. Organization for Economic Co-Operation and Development (OECD), Paris.

[4] Haider, R. (1992) Cyclone 91' Revisited. Bangladesh Center for Advanced Studies, Dhaka.

[5] Rashid, M.M., Hoque, A.K.F. and Iftekhar, M.S. (2004) Salt Tolerances of Some Multipurpose Tree Species as Determined by Seed Germination. Journal of Biological Sciences, 4, 288-292. https://doi.org/10.3923/jbs.2004.288.292 
[6] Ashraf, M.Y., Sarwar, G., Ashraf, M., Afaf, R. and Sattar, A. (2002) Salinity Induced Changes in $\alpha$-Amylase Activity during Germination and Early Cotton Seedling Growth. Biologia Plantarum, 45, 589-591. https://doi.org/10.1023/A:1022338900818

[7] Shahid, S. (2010) Impact of Climate Change on Irrigation Water Demand of Dry Season Boro Rice in Northwest Bangladesh. Journal of Climatic Change, 105, 433-453. https://doi.org/10.1007/s10584-010-9895-5

[8] Yadav, J.S.P., Sen, H.S. and Bandyopadhyay, B.K. (2009) Coastal Soils-Management for Higher Agricultural Productivity and Livelihood Security with Special Reference to India. Journal of Soil Salinity \& Water Quality, 1, 1-13.

[9] CCC (Climate Change Cell) (2007) Climate Change and Bangladesh. Department of Environment, Government of the People's Republic of Bangladesh, Dhaka.

[10] Singh, O.P., Khan, T.M.A. and Rahman, M.S. (2000) The Vulnerability Assessment of the SAARC Coastal Region Due to Sea Level Rise: Bangladesh Case. SAARC Meteorological Research Centre (SMRC), SMRC-No. 3, SMRC Publication, Dhaka.

[11] Karim, M.F. and Mimura, N. (2008) Impacts of Climate Change and Sea-Level Rise on Cyclonic Storm Surge Floods in Bangladesh. American Journal of Climate Change, 18, 490-500. https://doi.org/10.1016/j.gloenvcha.2008.05.002

[12] BBS (Bangladesh Bureau of Statistics) (2011) Population Census. Bangladesh Bureau of Statistics, Dhaka.

[13] Islam, M.R. (2004) Where Land Meets the Sea: A Profile of the Coastal Zone of Bangladesh. The University Press Limited, Dhaka.

[14] Gowing, J.W., Tuong, T.P. and Hoanh, C.T. (2006) Land and Water Management in Coastal Zones: Dealing with Agriculture-Aquaculture-Fishery Conflicts. In: Hoanh, C.T., Tuong, T.P., Gowing, J.W. and Hardy, B., Eds., Environment and Livelihoods in Tropical Coastal Zones. Managing Agriculture-Fishery-Aquaculture Conflicts, Comprehensive Assessment of Water Management in Agriculture Series No. 2, CABI Publishing, London, 1-16.

[15] World Bank (2000) Bangladesh: Climate Change and Sustainable Development. Report No. 21104 BD, Dhaka.

[16] Mahdy, A.M. (2011) Comparative Effects of Different Soil Amendments on Amelioration of Saline-Sodic Soils. Journal of Soil and Water Research, 6, 205-216. https://doi.org/10.17221/11/2011-SWR

[17] Shainberg, I., Summer, M.E., Miller, W.P., Farina, M.P.W., Pavan, M.A. and Fey M.V. (1989) Use of Gypsum on Soils: A Review. In: Stewart, B.A., Ed., Advances in Soil Science, Springer, Berlin, Vol. 9, 1-111. https://doi.org/10.1007/978-1-4612-3532-3_1

[18] Gupta, R.K. and Abrol, I.P. (1990) Salt-Affected Soils: Their Reclamation and Management for Crop Production. Journal of Advances in Soil Science, 11, 223-288. https://doi.org/10.1007/978-1-4612-3322-0_7

[19] Qadir, M. and Oster, J.D. (2002) Vegetative Bioremediation of Calcareous Sodic Soils: History, Mechanisms, and Evaluation. Journal of Irrigation Science, 21, 91-101. https://doi.org/10.1007/s00271-001-0055-6

[20] Maftoun, M. and Moshiri, F. (2008) Growth, Mineral Nutrition and Selected Soil Properties of Lowland Rice, as Affected by Soil Application of Organic Wastes and Phosphorus. Journal of Agricultural Science and Technology, 10, 481-492.

[21] Wang, Z.Q. and Li, L.Q. (1990) Salinization in China and Its Prevention, Studies on the Prevention of Land Degradation in China. Chinese Science and Technology Press, Beijing. 
[22] Gomez, K.A. and Gomez, A.A. (1984) Statistical Procedure for Agricultural Research. 2nd Edition, International Rice Research Institute, Willey International Science Publication, Los Baños, 28-192.

[23] USDA (United States Department of Agriculture) (2004) Soil Survey Laboratory Manual. Soil Survey Investigation, Report No. 42, Version 4, USDA-NRCS, USDA, Washington DC.

[24] Jackson, M.L. (1967) Soil Chemical Analysis. Prentice Hall of India Private Limited, New Delhi, 498 p.

[25] Jackson, M.L. (1962) Soil Chemical Analysis. Prentice Hall Inc., Englewood Cliffs.

[26] Piper, C.S. (1950) Soil and Plant Analysis. The University of Adelaide Press, Adelaide.

[27] Jackson, M.L. (1973) Soil Chemical Analysis. Prentice Hall of India Pvt. Ltd., New Delhi, 106-203.

[28] Bohn, H.L., Mcneal, B.L. and O'connor, G.A. (2001) Soil Chemistry. John Wiley and Sons Incorporation, New York.

[29] SAS (1988) SAS/STAT User's Guide. No. 1, ANOVA, Version 6, 4th Edition, Statistical Analysis System Institute, Cary.

[30] Sharma, D.P., Mchta, K.K. and Yadav, J.S.P. (1982) Effect of Reclamation Practices on Soil Properties and Crop Growth on Farmers' Fields. Journal of the Indian Society of Coastal Agricultural Research, 29, 356-360.

[31] Rehman, H., Abdel, A., Dahab, M.H. and Mustsfa, M.A. (1996) Impact of Soil Amendments on Intermittent Evaporation, Moisture Distribution and Salt Redistribution in Saline-Sodic Clay Soil Columns. European Journal of Soil Science, 67, 793-802. https://doi.org/10.1097/00010694-199611000-00008

[32] Haq, I.U., Habib, U.R., Niazi, B.H. and Saleem, M. (2001) Effect of Horizontal Flushing on the Reclamation of Sodic Soils and Yield of Fodder Crops after Gypsum Application. International Journal of Agriculture and Biology, 3, 323-325.

[33] Guidi, G. and Hall, J.E. (1984) Effect of Sewage Sludge on the Physical and Chemical Properties of Soils. Journal of Indian Society of Soil Science, 29, 129-131.

[34] Oster, J.D. and Shainberg, I. (2001) Soil Responses to Sodicity and Salinity: Challenges and Opportunities. Soil Research, 39, 1219-1224.

https://doi.org/10.1071/SR00051

[35] Chorom, M. and Rengasamy, P. (1997) Carbonate Chemistry, pH and Physical Properties of an Alkaline Sodic Soil as Affected by Various Amendments. Australian Journal of Soil Research, 35, 149-161. https://doi.org/10.1071/S96034 


\section{Appendix}

\section{Appendix I. Mean Value of Soil Parameters after 45 Days of} Incubation Compare to Reference Soil

\begin{tabular}{ccccccccc}
\hline Treatments & $\begin{array}{c}\mathrm{EC} \\
\left(\mathrm{ds} \cdot \mathrm{m}^{-1}\right)\end{array}$ & $\mathrm{pH}$ & SAR & $\begin{array}{c}\mathrm{CEC} \\
(\mathrm{C} \text { olc }(+) \\
\left.\mathrm{kg}^{-1}\right)\end{array}$ & $\begin{array}{c}\text { Organic } \\
\text { carbon } \\
(\%)\end{array}$ & $\begin{array}{c}\text { Organic } \\
\text { matte } \\
(\%)\end{array}$ & $\begin{array}{c}\text { Total } \\
\text { nitrogen } \\
(\%)\end{array}$ & C:N ratio \\
\hline $\mathrm{T}_{0}$ & $8.30 \mathrm{a}$ & $8.44 \mathrm{a}$ & $2.01 \mathrm{a}$ & $20.40 \mathrm{~d}$ & $0.78 \mathrm{c}$ & $1.34 \mathrm{c}$ & $0.14 \mathrm{c}$ & $5.59 \mathrm{c}$ \\
$\mathrm{T}_{1}$ & $6.91 \mathrm{~d}$ & $8.32 \mathrm{~b}$ & $1.45 \mathrm{~b}$ & $22.39 \mathrm{c}$ & $0.89 \mathrm{~b}$ & $1.53 \mathrm{~b}$ & $0.21 \mathrm{a}$ & $4.24 \mathrm{c}$ \\
$\mathrm{T}_{2}$ & $7.67 \mathrm{~b}$ & $8.22 \mathrm{~d}$ & $1.10 \mathrm{c}$ & $25.05 \mathrm{~b}$ & $0.87 \mathrm{~b}$ & $1.49 \mathrm{~b}$ & $0.18 \mathrm{~b}$ & $4.84 \mathrm{c}$ \\
$\mathrm{T}_{3}$ & $5.58 \mathrm{f}$ & $8.20 \mathrm{~d}$ & $1.02 \mathrm{c}$ & $21.73 \mathrm{c}$ & $0.7 \mathrm{e}$ & $1.20 \mathrm{e}$ & $0.08 \mathrm{~d}$ & $8.84 \mathrm{~b}$ \\
$\mathrm{~T}_{4}$ & $6.18 \mathrm{e}$ & $8.27 \mathrm{c}$ & $1.01 \mathrm{c}$ & $19.73 \mathrm{~d}$ & $0.74 \mathrm{~d}$ & $1.27 \mathrm{~d}$ & $0.05 \mathrm{e}$ & $14.24 \mathrm{a}$ \\
$\mathrm{T}_{5}$ & $7.23 \mathrm{c}$ & $8.32 \mathrm{~b}$ & $1.10 \mathrm{c}$ & $21.73 \mathrm{c}$ & $0.95 \mathrm{a}$ & $1.63 \mathrm{a}$ & $0.177 \mathrm{~b}$ & $5.38 \mathrm{c}$ \\
$\mathrm{T}_{6}$ & $5.14 \mathrm{~g}$ & $8.27 \mathrm{c}$ & $1.04 \mathrm{c}$ & $27.72 \mathrm{a}$ & $0.57 \mathrm{f}$ & $0.98 \mathrm{f}$ & $0.04 \mathrm{f}$ & $13.26 \mathrm{a}$ \\
\hline
\end{tabular}

